\title{
The Series of Leaflets as Media for Education, Promotion and Monitoring of Exclusive Breastfeeding
}

\author{
Debby Yulianthi Maria \\ STIKES Surya Global Yogyakarta, Yogyakarta, 53235, Indonesia \\ Email: debby.yuliathi@gmail.com \\ Dwi Hariyanti and Bety Agustina Rahayu \\ STIKES Surya Global Yogyakarta, Yogyakarta, 53235, Indonesia \\ Email: \{hariayanti.ssg@gmail.com, betyagustinarahayu@yahoo.co.id \}
}

Received: 02 November 2019; Accepted: 08 May 2020; Published: 08 June 2020

\begin{abstract}
Mother's knowledge about the importance of exclusive breastfeeding is a problem that determines the success of exclusive breastfeeding. Information support is needed to increase the mother's knowledge. This research create an acceptable media for increasing breastfeeding mother's knowledge of exclusive breastfeeding. This research uses the action research method. There are 5 stages including diagnosis, making an action plan, acting, evaluating and learning. The informants of this research are the baby mothers, maternal and child health services cadres and the breastfeeding counseling team at the Pleret health centre. Data collection instruments and techniques using questionnaires and interviews. Credibility test with technical triangulation, which was analyzed using theories from Milles and Huberman. The creation of a series of leaflet media about exclusive breastfeeding guidelines consisting of six series. Leaflets are made attractive in terms of design. This series of leaflet media effective as an educational and promotional media about exclusive breastfeeding.
\end{abstract}

Index Terms-Leaflet Media, Education, Promotion, Monitoring, Exclusive Breastfeeding

\section{INTRODUCTION}

Mother's knowledge about the importance of exclusive breastfeeding is an issue that determines the success of exclusive breastfeeding. Working mothers do not have enough time to attend maternal and child health services activities or other extension activities. The reason for this working mother is that it causes no information to be conveyed about the importance of exclusive breastfeeding. Due to the bad baby does not get the right to obtain exclusive breastfeeding [1].

Various attempts have been taken to improve the granting of exclusive breastfeeding, one of them is health promotion. Nonetheless, the health promotion has not shown the optimal result especially on the use of media.
The objective of this study was to determine the effect of health promotion regarding exclusive breastfeeding on the knowledge improvement of pregnant mothers either by using leaflet [2].

Data from the Ministry of Health of the Republic of Indonesia and Ministry of defense data and information center figures for exclusive breastfeeding in Indonesia were $35.7 \%$ in 2017 [3,4,5,6]. This figure is far from the WHO recommendation, which is $50 \%$. Yogyakarta City has implemented local regulation No. 1 of 2014 concerning exclusive breastfeeding. According to the city's Health Department notes, exclusive breastfeeding has doubled from 30 percent to 60 percent. In 2017, it is targeted that exclusive breastfeeding will reach up to 70 percent $[7,8]$.

From the results of preliminary studies that have been carried out there are data on 7 baby mothers who do not provide exclusive breastfeeding in the white lotus maternal and child health services area of Pungkuran Pleret Bantul in 2019. The second problem comes from maternal and child health services cadres, maternal and child health services cadres feel they do not have enough qualifications and information to provide health education and promotion about exclusive breastfeeding.

Preliminary about maternal and child health services, maternal and child health services does not have media that is used to provide information about exclusive breastfeeding. Maternal and child health services cadres feel they do not have enough qualifications or ability to provide counseling and time to provide counseling is also less effective because there is no specific agenda, where maternal and child health services activities are only registration, weight weighing, measurement of head and arm belly circumference, and finally supplementary feeding. So there is no special time for counseling, considering the baby's mother must also immediately go to work. Sometimes in a toddler maternal and child health services activity, babies are delivered not by their mothers but by grandmothers or care givers. This has 
become one of the problems inhibiting the delivery of information.

This is different from the theory that should be about maternal and child health services. Based on Maternal and child health services activities, the organization of Maternal and Child Health Services is divided into 5 tables, namely: a) Table I for registration, either underfive, pregnant mother or EFA. B) Table II for toddler weighing and measurement of LILA of pregnant mother and EFA. C) Table III for the registration of toddlers, pregnant women, and PUS / WUS. D) Table IV for counseling. E) Table $\mathrm{V}$ for health services and family planning [5].

The third problem from the Pleret Bantul Community Health Center cannot always be present in the monthly activities at the maternal and child health services. Lack of human resources is the reason for his absence in the toddler maternal and child health services agenda.

Achievement of exclusive breastfeeding in the Pleret Bantul region has not reached $100 \%$. The results of interviews conducted with the exclusive breastfeeding counseling team obtained data on exclusive breastfeeding promotion activities only carried out in activities held by health centers that invite Maternal and child health services cadres, and counseling when the baby's mother comes to the nutrition room and KIA to check the child. The lack of human resources in the community health center especially in the nutrition section causes the maximum lack of exclusive breastfeeding counseling teams to promote exclusive breastfeeding [6]. Promotion and monitoring of exclusive breastfeeding is done by the 24-hour recall method. This 24-hour recall method is performed on infants 0-6 months and 6-24 months [8,10].

Knowledge about the importance of exclusive breastfeeding and its monitoring needs to be done to achieve the ultimate goal of nutritional success for infant development. Corrective action must be taken immediately to achieve these goals. One of the steps that can be taken is the provision of education or information that is right on target, namely the mother of children under five. In addition, supporting factors that influence the knowledge of mothers about exclusive breastfeeding, such as the role of cadres in integrated service center, must also be improved. So that knowledge must also be given as a whole, namely to cadres of integrated service center toddlers as well.

The problems presented by respondents in this study, the researchers plan to create innovative media that are interesting, effective, and efficient in the hope that they will assist the exclusive breastfeeding primary health care counseling team or maternal and child health services cadres in exclusive breastfeeding promotion activities. It is hoped that the achievement of exclusive breastfeeding in the work area of Pleret community health center health care will increase to $100 \%$.

From preliminary study, this research appropriate if using action research method to solve existing problems. Learning media can be used as an aid that enhances thought, feeling, attention, and interest. Leaflet as learning media showed significant knowledge improvement in exclusive breastfeeding [8]. For mother baby, pictures and benefit from media can increase learning activity [9].

Based on the results of the preliminary study, this research wants to conduct action research aimed at solving existing problems. This study wants to find out whether there is effectiveness in the use of learning media, namely serial leaflets to increase knowledge, promotion and monitoring of exclusive breastfeeding in working mothers.

\section{METHOD}

This research was approved by the Health Research Ethical Committee STIKES Surya Global Yogyakarta (Number: 244/KEPK/SG/VII/2019) before the data were collected. This research was conducted in Pleret Bantul Yogyakarta from of Mei to October 2019

This research uses an action research method. In this action research, the researcher conducted a description, interpretation, and explained the social situation to change changing behavior for good by giving an intervention. The purpose of the action research method is a problem-solving research framework [10]. The other reason use of this action research method is based because researchers want to know the needs, responses and expectations of toddlers about providing information on achieving exclusive breastfeeding. Other than that this method was chosen to improve the implementation of promotional activities by using serially arranged leaflets.

Action research, as a method of inquiry, is founded on the assumption that theory and practice can be closely integrated by learning from the results of interventions that are planned after a thorough diagnosis of the problem context. There are five stages in action research consisting of the stages of diagnosis, making an action plan, taking action, evaluating and learning. Action research refers to a wide variety of evaluative, investigative, and analytical research methods designed to diagnose problems or weaknesses whether organizational, academic, or instructional and help educators develop practical solutions to address them quickly and efficiently $[11,12]$.

Action research may also be applied to programs or educational techniques that are not necessarily experiencing any problems, but that educators simply want to learn more about and improve. The general goal is to create a simple, practical, repeatable process of iterative learning, evaluation, and improvement that leads to increasing breastfeeding better results for schools, teachers, or programs. Action research may also be called a cycle of action or cycle of inquiry, since it typically follows a predefined process that is repeated over time [10].

To increase the validity of this action research, researchers asked for additional information through interviews, distributing questionnaires and observations to the baby's mother, cadres, and ASI counseling team from the community health services. The questionnaire 
was used to collect data related to the achievement of exclusive breastfeeding in baby's mothers. Interviews were carried out to baby's mothers to examine the failure constraints of exclusive breastfeeding, as well as the constraints of maternal and child health services cadre mothers and the exclusive breastfeeding counseling team at the community health center in providing exclusive breastfeeding promotions [2].

The results of the data collected will be carried out data reduction, data presentation, and drawing conclusions in accordance with Milles and Huberman's analysis, and triangulation technique was used in the credibility test of this study [12].

\section{RESULTS}

\section{Characteristics of Baby Mothers Respondents}

There are 7 informants who participated in this study. Respondents in this study were informants who did not exclusively breastfeed their babies. From the results of the study, the characteristics of the age of respondents were in the early adult category (26-35 years) as many as 5 people $(71.43 \%)$ and late adulthood (36-45 years) as many as 2 people $(28.57 \%)$. The last education of mothers in the low education category was 4 people $(57.14 \%)$ and 3 people $(42.86 \%)$ with secondary education.

Mothers with jobs as laborers were 4 people $(57.14 \%)$, 2 people $(28.57 \%)$ as traders, and 1 person $(14.29 \%)$ as private employees. Four mothers $(57.16 \%)$ had 2 children, 1 mother (14.28\%) had 1 child, 1 mother (14.28\%) had 3 children, and 1 mother $(14.28 \%)$ had 4 children. Income of 3 mothers $(50 \%)$ conversational $<1,000,000.00$ rupiah and 3 other mothers $(50 \%)$ between 1,000,000.00 rupiah $1,500,000.00$ rupiah. Six mothers $(85.71 \%)$ said they had received exclusive breastfeeding counseling, and 1 mother (14.29\%) did not. Three mothers (42.86\%) said they received breastfeeding counseling, and 4 mothers $(57.14 \%)$ did not receive breastfeeding counseling.

\section{Characteristics of Maternal and Child Health Services} Cadres

The majority of cadres were in late adulthood (36-45 years) as many as 8 people $(72.72 \%)$, and 3 people $(27.27 \%)$ entered the early elderly age (46-55 years). Last education 10 cadres $(66.67 \%)$ included in the breastfeeding education category and $5(33.33 \%)$.

\section{Characteristics of the breastfeeding health center counseling team}

There were 11 exclusive breastfeeding counseling teams at the Pleret Community Health Center. Four people $(36.36 \%)$ fall into the early adulthood category (26-35 years) and seven people $(63.64 \%)$ fall into the early age category (46-55 years). Last education 11 people $(100 \%)$ entered tertiary education consisting of midwifery and nutrition. Ten people $(90.90 \%)$ are civil servants and a freelance daily employee. (9.10\%). One person has worked for 10-20 years, 4 people worked 21 -
30 years, 3 people worked 31-41 years, and 3 people worked 41-50 years. One person monthly salary < 2,000,000.00 rupiah, 3 people with a salary of Rp. 2,000,000.00 - 3,000,000.00 rupiah, and 7 people with a salary of more than 3,000,000.00 rupiah.

\section{Action Research}

Action research is a tool that is used to help educators uncover strategies to improve teaching practices [18], it is viable endeavor for all educators. Action research may also be called a cycle of action or cycle of inquiry, since it typically follows a predefined process that is repeated over time. Stage of action research is identify a problem to be studied, collect data on the problem, organize, analyze, and interpret the data, develop a plan to address the problem, implement the plan, evaluate the results of the actions taken, identify a new problem and the last is repeat the process. The following result of action research in this study are :

\section{The first stage}

This stage consists of diagnosing, researchers conducting surveys of problems by distributing questionnaires about the success and knowledge of exclusive breastfeeding to mothers of children under five. In addition to the survey using questionnaires for mothers of toddlers, interviews were also conducted to examine the causes of exclusive breastfeeding failure. The survey was also conducted on maternal and child health services cadres and breastfeeding counseling teams from the Pleret community health center on the issue of the success of exclusive breastfeeding in the working area with interview techniques.

The problem that was found during the survey with the baby's mother found that there were 7 mothers out of 40 respondents who failed to give exclusive breastfeeding. The mother worked outside the home so she had to leave the child for some time. Mother feels inconvenienced to express milk at work. The existence of physical problems in the mother such as nipple is not prominent, breastfeeding does not come out and pain during breastfeeding is also conveyed by the baby's mother as a reason for not giving exclusive breastfeeding. Mother's knowledge about the importance of exclusive breastfeeding is an issue that determines the success of exclusive breastfeeding. The factor of working outside the home is also the reason for the failure of exclusive breastfeeding and also the cause of the absence of Maternal and Child Health Services activities. The reason for this working mother is that it causes no information to be conveyed about the importance of exclusive breastfeeding. Due to the bad baby does not get the right to obtain exclusive breastfeeding.

Look at the condition that there is knowledge and motivation of the mother which is the problem of not exclusive breastfeeding. The decrease knowledge and motivation about the important of exclusive breastfeeding will impact to the scope application of exclusive breastfeeding until be needed healthy promotion than can motivated mother for give suck in a exclusive manner 
requirements like utilize leaflet as information media for upgrade motivation and knowledge [13].

The second problem comes from Maternal and Child Health Services cadres, Maternal and Child Health Services cadres feel they do not have enough qualifications and information to provide health education and promotion about exclusive breastfeeding. Maternal and Child Health Services does not have media that is used to provide information about exclusive breastfeeding. Some of the reasons that became the obstacle of the community health center have not reached the target of $100 \%$ exclusive breastfeeding achievement. The results of the interviews that have been made explaining that the lack of human resources in the community health center, especially in the nutrition section, makes it less possible for the breastfeeding counseling team to promote exclusive breastfeeding in every Maternal and Child Health Services activity. Maternal and Child Health Services only provides health promotion when the baby's mother visits the community health center. Promotion and monitoring of exclusive breastfeeding is done by the 24-hour recall method. This 24-hour recall method is performed on infants 0-6 months and 6-24 months.

Seeing the problems that exist, researchers devise solutions to the problems at hand. Researchers are trying to increase the mother's knowledge about the importance of exclusive breastfeeding, which hopes will change the perception, attitudes, and behavior of mothers in breastfeeding for the better $[15,16]$. Researchers plan to create effective and innovative educational media. Seeing the ability and condition of mothers of children under five who are still in rural areas with the majority of low and secondary education, researchers plan to compile print media in the form of leaflets that are made serially to direct mothers of toddlers to reach exclusive breastfeeding [16].

The planned media are leaflets that are made in series ranging from 1 month until 6 months. Leaflets are made with an attractive design that allows readers to read and not discard this leaflet. Besides being useful for information delivery, this leaflet will be planned in a form so that it can provide other benefits.

\section{The second stage}

The second stage is that the researchers make a plan of action. The researchers designed the contents of the leaflet in each series. Researchers then began to design a leaflet design using the help of Corel Draw to design leaflets as expected. After the leaflet, the researchers printed out an expert test, namely the medical education specialist and nursing education specialist to provide an assessment and input on the media that has been made. Then the researchers improved the media of this leaflet according to the direction of the expert.

\section{The third stage}

The third stage is the researchers take action. The action referred to here is that researchers begin to socialize and promote exclusive breastfeeding using serial leaflet media. Researchers worked with maternal and child health services cadres and the breastfeeding community health center Pleret counseling team to take advantage of this educational media as a media to promote or promote exclusive breastfeeding.

\section{The fourth stage}

In the fourth stage, the researchers conducted an evaluation of the serial leaflet media. The evaluation was conducted by interviewing media users, namely baby mothers, maternal and child health services cadres, and the Pleret Community Health counseling team about serial leaflet media. Evaluations include design, information content, and usefulness of leaflets. Fifteen Maternal and Child Health Services cadres, seven baby mothers, and eleven exclusive breastfeeding counseling teams at the Pleret Public Health Center stated that this leaflet was quite interesting in terms of design, color, content and had other benefits so that readers felt reluctant and felt pity to throw it away. The results of interviews with respondents regarding the evaluation of this media are as follows:

"Leaflets are already attractive both in image and color. The contents are good for giving information to mothers of toddlers about the steps to pass exclusive breastfeeding every month. Can be used as a cadre guide for your counseling "(P)

"Interesting is good, it has other benefits, so it is not right if you throw it away. The contents are also good at giving an overview of ways to provide exclusive breastfeeding "(F)

"The leaflets are good, interesting, providing important information and other benefits of this leaflet, so it's a shame to throw them away. This leaflet can also provide coherent information in order to exclusively breastfeed for up to six months "(E)

\section{The fifth stage}

The fifth stage is learning, this stage is the final part where researchers conduct a review of the stages that have been passed. At the diagnosis, stage researchers have found a problem. Researchers have also planned solutions to overcome the existing problems by creating serial leaflets aimed at increasing breastfeeding the knowledge of infant mothers about exclusive breastfeeding, providing media to maternal and child health services cadres and medical health care counseling teams as a means of providing information. Leaflets have been made in six series according to the time of exclusive breastfeeding, leaflets containing information related to exclusive breastfeeding.

\section{DISCUSSION}

The mother of the baby who was a participant was in early adulthood and late adulthood. Mother is in a mature period both in terms of understanding and making decisions. According to Erlin research the more mature a person's age the experience of his life is also more, age 
influences one's comprehension and mindset. Increasing breastfeeding age will further develop one's mindset and capture power so that the knowledge gained is also increasing breastfeeding [17].

The majority of working toddlers have a number of 2 children, with already having previous children, the mother has prior experience in caring for and breastfeeding her child. Similarly, the more positive aspects of the object that are known it will foster a positive attitude towards the object. Conversely, if according to Middlebrook in Azwar says there is no experience possessed by someone with an object then it tends to form a negative attitude towards the object [18].

Mother of toddlers working in this study with the last education is low and secondary schools. With a monthly income of less than 1,500,000 rupiah. The development of increasing breastfeeding fast times, in line with the increasing breastfeeding needs of life. Then the need for economic status also greatly influences the availability of facilities needed for certain activities in this case blushing breastfeeding. Sources of information obtained by mothers also require costs or the economy. Information can be obtained through electronic mass media or print mass media, mothers can browse or buy reading books as a source of information, in other words, the economy also affects a person to increase knowledge.

With the presence of this series of leaflet media, it is hoped that it will help the baby's mother in increasing breastfeeding her knowledge. Leaflet according to Notoadmojdo is a piece of paper containing writing with short sentences, dense, easy to understand, and the tone of simple images [8]. Leaflets in Syamsiah's research affect respondents' knowledge and intentions. The leaflet media is also effective in increasing breastfeeding the knowledge and skills of washing hands with soap in Sang Surya female students at the Muhammadiyah University of Malang [19].

From the problems found in the diagnosis stage, researchers have formulated the problem of the need for increased knowledge both of the baby's mother and the Maternal and Child Health Services cadre. Efforts to increase knowledge have been created serial leaflets about exclusive breastfeeding. In the second stage, researchers have created a 6 series leaflet, which provides information on how to achieve exclusive breastfeeding in each month.

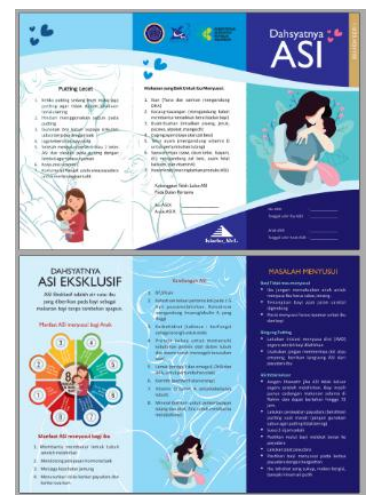

Fig.1. Serial leaflet 1

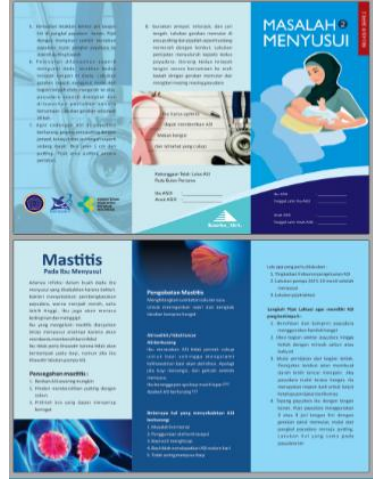

Fig.2. Serial leaflet 2

Figure 1. Series 1 leaflet with the title of the enormity of the breastfeeding series. This leaflet series 1 provides information about the benefits of exclusive breastfeeding for babies and mothers, the content of breastfeeding, problems that are often experienced in nursing mothers in the first month and its handling, and good food for nursing mothers.

Figure 2. Series 2 leaflet with the title breastfeeding problems in the second month and how to overcome them.

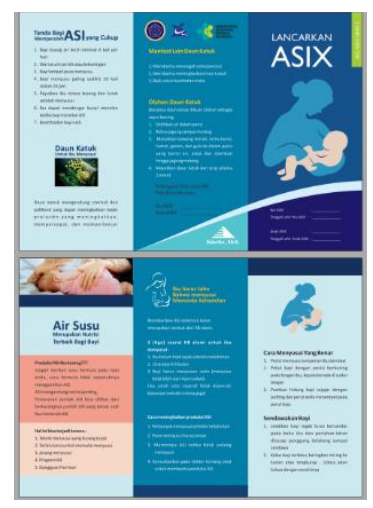

Fig.3. Serial leaflet 3

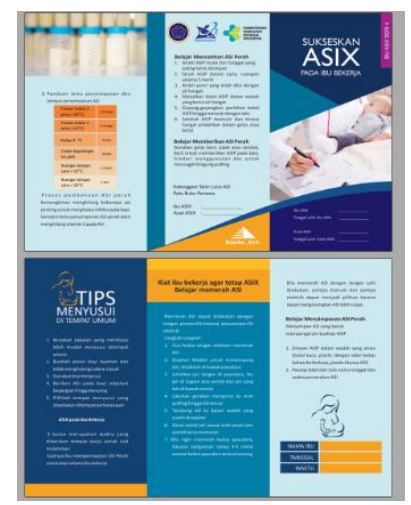

Fig.4. Serial leaflet 4

Figure 3. Series 3 leaflet with the title smooth out breastfeeding $\mathrm{X}$, breastfeeding $\mathrm{X}$ is a term that is made with the meaning of "Exclusive" breastfeeding-X or ASIX which is breastfeeding "6 months". This series provides information about ways to facilitate breastfeeding and the benefits of breastfeeding in contraception. 
Figure 4. The fourth series of this leaflet is titled breastfeeding X success in working mothers. Considering the baby's age of four months is a period in which the working mother has finished passing her maternity leave rations. In this series, some information is provided for working mothers to be able to provide exclusive breastfeeding. The information provided includes how to express milk, store breastfeeding, dilute milk and give milk to babies.

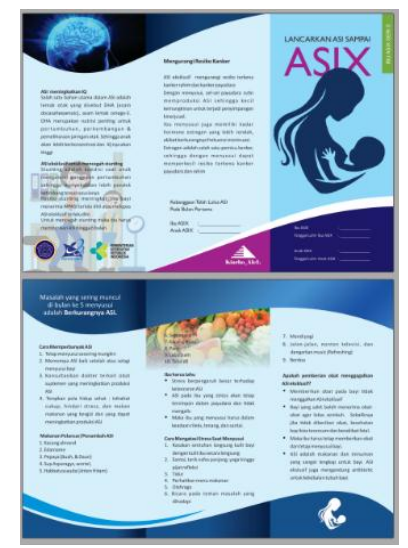

Fig. 5. Serial leaflet 5

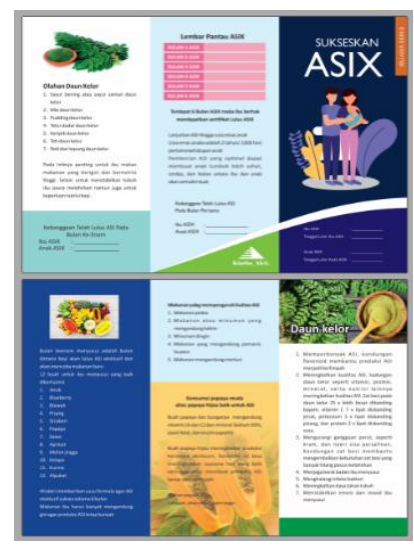

Fig.6. Serial leaflet 6

Figure 5. The fifth series in this leaflet is titled breastfeeding to breastfeeding $\mathrm{X}$, the purpose of this 6 th leaflet is to provide information so that mothers can continue to give breastfeeding for at least 6 months. In this series tips on multiplying breastfeeding, smoothing breastfeeding and additional information about the benefits of breastfeeding are conveyed in detail.

Figure 6. The sixth session is the last series with the title breastfeeding $\mathrm{X}$ success. Considering that breastfeeding for working mothers there must be a change in the volume of milk produced, so in this series is given information about supplementary foods that help increase breastfeeding.

This leaflet is designed as a healthy health card owned by each baby to monitor their growth and development. This leaflet has an identity column where this column is made so that the mother has the responsibility or obligation to provide exclusive breastfeeding to her baby. The hope is that this identity column will increase the motivation and confidence of mothers to provide exclusive breastfeeding.

The identity column contains the mother's name, mother's birthday, child's name, and the child's birthday. The child's date of birth must be in accordance with the serial leaflet. Children who are at the age of 1 month then the mother should hold the series 1 leaflet, if the baby is 2 months old the mother must write and hold the series 2 leaflet and so on. Mothers with babies at 2 months should have series 1 and 2. Mothers with babies at 3 months should have series 1,2 , and 3 and so on. So if the baby is 6 months old, the mother has all the serial leaflets.

In each leaflet in addition to containing information that is one of the benefits of the leaflet, namely as a media to promote education about exclusive breastfeeding, this leaflet has a column of monitoring sheets in each series in the pride column and at the end of the sixth series which is a sheet of monitoring breastfeeding for up to 6 months at figure 7 .

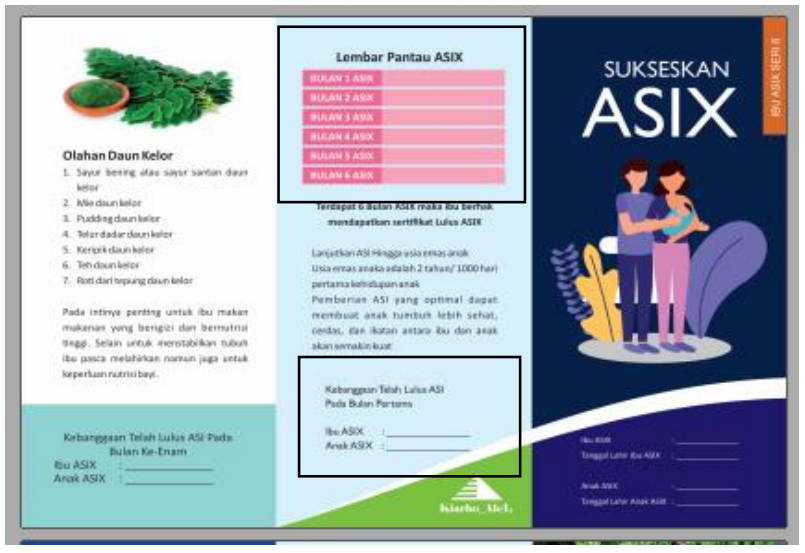

Fig.7. Monitoring Sheet

Mothers who have passed exclusive breastfeeding will get a certificate of passing breastfeeding. This certificate is only given to mothers who have successfully breastfed for 6 full months for their babies.

Returning to work is a common reason for stopping breastfeeding or for deciding not to start breastfeeding, however services can inform mothers that the provision of breastfeeding can be supported in their Service. A leaflet is a little book or a piece of paper containing information about a particular subject [13].

Result of this research is a serial leaflet. This leaflet has been revised in accordance with expert input regarding the contents and color of the leaflet. In the third stage the researchers distributed leaflets to the Maternal and Child Health Services cadres and the exclusive breastfeeding counseling team at the Pleret community health center, researchers also conducted and conducted exclusive breastfeeding education using serial leaflet media. Researchers worked with Maternal and Child Health Services cadres and the breastfeeding Pleret community health center counseling team to take advantage of this educational media as a media to promote or promote exclusive breastfeeding. 
In the fourth stage, the researchers conducted an evaluation of the serial leaflet media, and the results were quite satisfying, Maternal and Child Health Services cadres, mothers of toddlers, and exclusive breastfeeding counseling teams agreed and would use the serial leaflet media as a media to promote and monitor exclusive breastfeeding. This leaflet has been evaluated to provide benefits including: content providing information about exclusive breastfeeding, leaflet media can be used as educational promotion media and leaflet media are designed to have sections or columns aimed at monitoring exclusive breastfeeding. In final fourth stage, the researcher felt there were no significant obstacles in carrying out the stages of each of the research processes.

The existence of this innovative leaflet media provides additional motivation for mothers of toddlers in achieving exclusive breastfeeding for their baby. Mothers get knowledge about the benefits and importance of breastfeeding for their babies, mothers get information what if the child is not given exclusive breastfeeding, mothers get information on how to smoothen breastfeeding and overcome problems that might occur in nursing mothers.

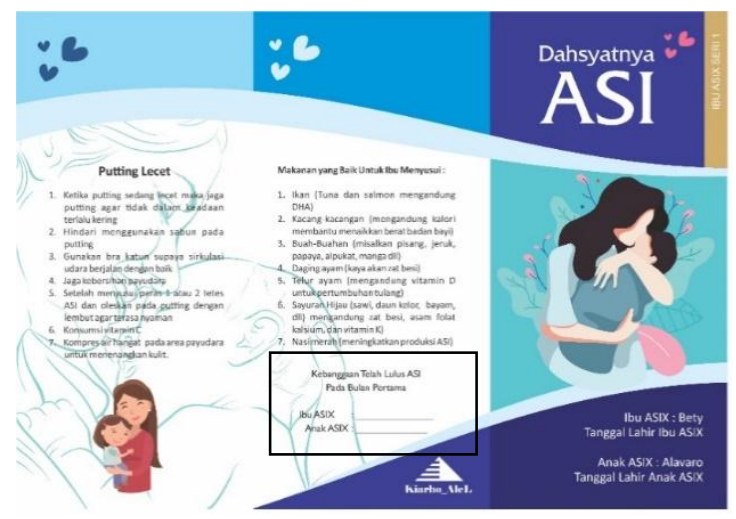

Fig.8. Pride Column

This is an example of a pride column which is an innovation of this leaflet. Mothers will be encouraged to provide exclusive breastfeeding so that they can fill the pride column for giving exclusive breastfeeding to their children. Mother have the right to write in the column if you have given exclusive breastfeeding for the month according to the series. This indirectly has a positive impact on achieving exclusive breastfeeding in Indonesia.

Various studies have recognized that the educational media, leaflets, have a positive impact on increasing breastfeeding the reader's knowledge. The use of leaflets in this action research is due to the analysis of knowledge and income sources or economics that is in the sufficient category. So that the leaflet is considered the right media to be used for education about exclusive breastfeeding, with the addition of content or innovation in it.

Learning is the fifth stage, this stage is the final part where researchers conduct a review of the stages that have been passed. Problem knowledge is found this research. Creating serial leaflets is solutions to overcome the existing problems. This serial leaflets providing media to mother baby, maternal and child health services cadres and medical health care counseling teams as a means of providing information. Leaflets have been made in six series according to the time of exclusive breastfeeding, leaflets containing information related to exclusive breastfeeding.

The five stages of this action research are the stages of a planned, systematic, and cyclical approach to understanding the learning process and analyzing the needs of the baby's mother in achieving exclusive breastfeeding. Researchers can access research findings directly and make improvements to ideas and enter existing ones.

With this action research, it has helped working mothers, maternal and child health services cadres, and medical health care counseling teams to improve the achievement of exclusive breastfeeding for working mothers in the maternal and child health services Teratai Putih area of Pungkuran Pleret Bantul. This leaflet provides the right information for nursing mothers. So it can be said this media can be used for health promotion related to exclusive breastfeeding. This leaflet can also provide benefits to monitor or monitor the achievement of exclusive breastfeeding in nursing mothers. So in addition to the 24-hour recall method used by the medical health care, the medical health care also gets valid data from the mother every month regarding exclusive breastfeeding which is also monitored by the cadre of the under-five Maternal and Child Health Services.

This leaflet is a media for connecting information from mothers, maternal and child health services cadres and medical health care in collecting data on exclusive breastfeeding. Seeing the good results of this study, it is hoped that this media can be utilized by maternal and child health services or other medical health care work areas. Researchers can then develop additional information content or other information updates to improve the achievement of exclusive breastfeeding.

This result of research same with Katherine action research is a tool for improving teacher quality and classroom practice [9]. Action research involves actively participating in a change situation, often via an existing organization, whilst simultaneously conducting research [20].

\section{CONCLUSION}

The leaflet series can be utilized by the ASI counseling team for community health centers, cadres of integrated service centers and working mothers as a media to provide information, promotional media and exclusive breastfeeding monitoring. The increase in the number of mothers giving exclusive breastfeeding is evident from the results of monitoring that has been provided in this serial leaflet. So it can be concluded that the leaflets are effective as a medium for education, promotion and monitoring of exclusive breastfeeding. 


\section{ACKNOWLEDGMENT}

Our gratitude goes to RISTEKDIKTI who has been willing to fund the research carried out until the end. In addition, we would like to thank STIKES Surya Global which has provided an opportunity in the process of conducting this research

\section{REFERENCES}

[1] R. M. Davison, M. G. Martinsons, and N. Kock, "Principles of Canonical Action Research," Info Syst. J, vol. 14, pp. 65-86, 2004.

[2] WHO and UNICEF, Breastfeeding Counselling A Training Course. 2015.

[3] D. Budijanto, "Data dan Informasi Profil Kesehatan Indonesia 2017," Indonesia, 2018.

[4] Agung, "Pemberian ASI Eksklusif di Kota Yogyakarta Capai 60 Persen," Tirto id, Yogyakarta, 2017.

[5] S. Fikawati and A. Syafiq, "Penyebab Keberhasilan dan Kegagalan Praktik Pemberian ASI Eksklusif," J. Kesehat. Masy. Nas., vol. 4, no. 3, pp. 120-131, 2009.

[6] Mufdlilah, Kebijakan Pemberian ASI Eksklusif: Kendala Dan Komunikasi, 1st ed. Yogyakarta: Nuha Medika, 2017.

[7] W. B. Freire, "Nutrition and an Active Life," in Scientific and Technical Publication, no. 612, Washington DC: Pan American Health Organization, 2005.

[8] D. Mona and F. W. Azalea, "Leaflet and pocketbook as an education tool to change level of dental health knowledge," Bali Med. J. (Bali Med J), vol. 7, no. 3, pp. 760-763, 2018.

[9] K. A. O. Connor, H. C. Greene, and P. J. Anderson, "Action Research : A Tool for Improving Teacher Quality and Classroom Practice," ReseachGate, no. January, 2006.

[10] M. Elg, I. Gremyr, and A. Wallo, "Service Action Research: Review and Guidelines," J. Serv. Mark., vol. 34, no. 1, pp. 87-99, 2020.

[11] M. M. Manfra, "Action Research and Systematic, Intentional Change in Teaching Practice," Rev. Res. Educ. vol. 43, no. August, pp. 163-196, 2019.

[12] M. B. Miles and A. M. Huberman, Qualitative Data Analysis, 2nd ed. London New Delhi: SAGE Publications, 1994.

[13] G. A. Azeze, K. A. Gelaw, N. A. Gebeyehu, M. M. Gesese, and T. M. Mokonnon, "Exclusive Breastfeeding Practice and Associated Factors among Mothers in Boditi Town , Wolaita Zone , Southern Ethiopia , 2018: A Community-Based Cross-Sectional Study," Hindawi Int. J. Pediatr., vol. 1, 2019.

[14] Y. Hasibuan and A. Batubara, "Mother' s Role and Knowledge in Young Children Feeding Practices on the Nutritional Status of Infant and Toddler," Glob. J. Health Sci., vol. 11, no. 6, pp. 158-168, 2019.

[15] E. Gamelia, D. Anandari, and D. U. Purnamasari, "RuralBased Health Promotion Model for Pregnant Women in Banyumas District," Kesmas Natl. Public Heal. J., vol. 11, no. 1, pp. 7-13, 2016.

[16] A. C. Adisasmita, S. Maemun, W. Sari, and S. Choirunisa, "Strategies to Promote Six Months of Exclusive Breastfeeding: A Review of Theses and Undergraduate Theses of Faculty of Public Health , University of Indonesia," Heal. Sci. J., vol. 10, no. 5:18, pp. 1-9, 2016.

[17] E. R. Saraswati, "Pengaruh Penyuluhan Cara Menyusui Yang Benar Terhadap Perilaku Pemberian ASI Minggu Pertama Pada Ibu Nifas Di RS PKU Muhammadiyah Yogyakarta," e-journal STIKES Aisyiyah, 2014.
[18] S. Azwar, Sikap Manusia, Teori dan Pengukurannya, 2nd ed. Yogyakarta: Pustaka Pelajar, 2015.

[19] N. Syamiyah, "Pengaruh Media Leaflet Terhadap Perubahan Pengetahuan Dan Intensi Pemberian ASI Eksklusif Pada Ibu Hamil Di Wilayah Puskesmas Kecamatan Pesanggrahan Jakarta Selatan Tahun 2013," UIN Syarif Hidayatullah Jakarta, 2013.

[20] D. by P. Health, "Encouraging \& Supporting Breastfeeding In Childcare Resource KIT," in Health Southern NSW Local Health District, no. July, 2015.

\section{Authors' Profiles}

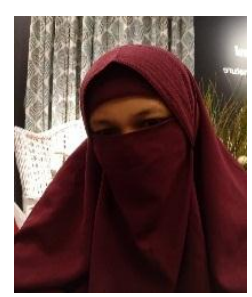

Debby Yulianthi Maria is a lecturer at STIKES Surya Global Yogyakarta. She was born in Ujung Pandang / July 28, 1975. She got my bachelor of dentistry from Hasanudin University, she also got a master's degree in health from Hasanudin University

She work experience, including as a NGO and now be a Lecturer in STIKES Surya Global Yogyakarta until 2015. STIKES Surya Global Yogyakarta location in South Ring road Selatan Blado Potorono Banguntapan Bantul Street; She ever get staff positions in career guidance for student in STIKES Surya Global Yogyakarta to.

She ever get grant funds research with title "Pengaruh periklanan terhadap keputusan konsumen (penderita hipertensi) memilih pengobatan herbal (studi kasus di Padukuhan Pungkuran Yogyakarta)" from DIPA in 2016. She ever be oral presentation in Inna Garuda Hotel in conference activity with title The $2^{\text {nd }}$ International Conference On Health Science 2015 "Optimizing The quality O Life Children Under SDGS".

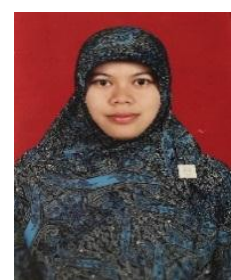

Dwi hariyanti is a lecturer in public health at STIKES Surya Global Yogyakarta. She get bachelor of public health degree was obtained at STIKES Surya Global Yogyakarta. The health master's degree was obtained from a BUDIDN scholarship. a master's degree in family medicine with an interest in the education of the health profession was obtained at Sebelas Maret Solo University.

Since the beginning of his career he has worked as a lecturer at STIKES Surya Global Yogyakarta. In addition to being a lecturer, she also had the mandate of accreditation. Now she is placed in the human resources development program and as a teaching lecturer in the classroom. She teaches reproductive health material. A lot of research and service experience has been carried out with funds from both internal universities and from external institutions such as RISTEKDIKTI.

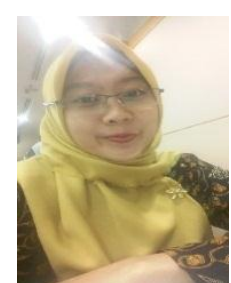

Bety Agustina Rahayu is a lecturer at STIKES Surya Global Yogyakarta. She graduated with a degree in nursing and a nursing profession at STIKES Surya Global Yogyakarta in 2014. She obtained a master's degree in nursing at the University of Muhammadiyah Yogyakarta in 2019.

She's work experience includes being a practicum laboratory assistant, having been a practicum instructor, having been a class lecturer. Now she is a practicum 
lecturer in the nursing study program, in addition to the lecturer she also gets the mandate as a quality assurance team at the STIKES Surya Global Yogyakarta.

She often participates in research grants and gets grants from DIPA and RISTEKSIKTI. She has an interest in researching. she has published a book on nutrition guidelines for toddlers and milk management. She also has a copyright related to breastfeeding's complementary food guide application, named PASIPEDIA. besides external grants he also often gets internal grants from STIKES Surya Global

How to cite this paper: Debby Yulianthi Maria, Dwi Hariyanti, Bety Agustina Rahayu, " The Series of Leaflets as Media for Education, Promotion and Monitoring of Exclusive Breastfeeding", International Journal of Information Engineering and Electronic Business(IJIEEB), Vol.12, No.3, pp. 19-27, 2020. DOI: 10.5815/ijieeb.2020.03.03 